\title{
Anthropometric and somatotype differences between $C 1$ paddlers who were and were not selected for the Czech national team
}

\author{
Jan Busta*, Ivana Kinkorová, James Joseph Tufano, Milan Bílý, Jiří Suchý
}

Faculty of Physical Education and Sport, Charles University, Prague, Czech Republic
* Corresponding author: buster@centrum.cz

\begin{abstract}
The objective of this study was to determine the anthropometric and somatotype differences between elite single-canoeists (C1) included in the white-water slalom Czech national team (NT) $(n=5)$ and others $(n=12)$ who did not qualify for the national team (DNQ) leading up to the Olympic Games in Rio de Janiero, 2016. All paddlers were measured using a battery of 40 anthropometric parameters in one day, 4 weeks before competing in the (zech national selection races. The NT racers had a significantly $(p<0.05)$ greater circumference of the forearm ( $27.8 \pm 0.6$ vs. $26.8 \pm 1.4)$ and upper arm (35.60 \pm 1.5 vs. $33.5 \pm 1.7)$ for the dominant paddling arm, as well as a greater chest circumference ( $98.3 \pm 2.4$ vs. $93.9 \pm 2.3$ ). Additionally, the sum of triceps, scapular, calf, and supraspinal skinfolds were significantly less in NT. There were no significant differences in height $(p=0.14)$, body mass $(p=0.18)$ or circumferences of the lower extremities $(p=0.09-0.32)$. Somatotype was statistically similar $(p=0.06-0.13)$, but practically different (NT = 1.4-5.6-2.3; DNQ = 1.6-4.6-3.1) such as body fat percentage ( $\mathrm{NT}=7.5 \pm 2.3$; DNQ $=9.1 \pm 1.6$ ). Based on the results of this study we can recommend that single-canoeists seeking to achieve elite performance should participate in training that focuses on maximizing the musculature of the upper limbs and chest while maintaining minimal body fat. The current data also shows that experience likely plays a role in national team selection, as NT were an average of 5.5 years older than DNQ.
\end{abstract}

\section{KEY WORDS}

Olympic games; canoe; white water; slalom; high performance athletes

DOI

10.14712/23366052.2018.5

(c) 2018 The Authors. This is an open-access article distributed under the terms of the Creative Commons Attribution License (http://creativecommons.org/licenses/by/4.0), which permits unrestricted use, distribution, and reproduction in any medium, provided the original author and source are credited. 


\section{INTRODUCTION}

White-water slalom is a canoeing event in which one must navigate through gates placed on river rapids as quickly as possible. Although the concept of the sport remains the same, white-water slalom competitions have undergone radical development over the past 20 years. For example, the duration of a typical race has shortened from over 200 seconds (s) to approximately $90-110$ s and the slaloms are becoming faster and more technical. Therefore, it is likely that success in the modern white-water slalom may largely depend on an athlete's strength levels, specifically rapid and explosive strength in the upper body, that is needed to navigate the canoe through hairpin turns within the rapids (Bílý, 2012). As the sport has evolved and the importance of strength and power output increases, it is probable that changes to the somatotypes and key anthropometric parameters of competitors have occurred over the years.

It is well known that somatotype and some anthropometric parameters may indicate whether an athlete would be suitable to participate at the highest level in canoe sprint. Specifically, certain anthropometric variables such as upper body anthropometric variables correlate with paddling performance (Fry \& Morton, 1991; Van Someren \& Palmer, 2003; Akca \& Muniroglu, 2008) and can be used during talent identification as well as providing areas to focus on during training (Gutnik et al., 2015). However, other studies carried out on canoe sprint have failed to find significant relationships between anthropometric parameters and performance on the race track (Dokumaci \& Çakir-Atabek, 2015; Van Someren \& Howatson, 2008). Therefore, data regarding the relationship between anthropometric measures and performance in canoe sprint has not been completely clarified scientifically. Furthermore, the body of literature is even smaller in white-water slalom, a canoeing event that includes a greater technical aspect and that may not be determined by physical factors to the same extent as in canoe sprint.

Ridge, Broad, Kerr, \& Ackland (2007) measured anthropometric variables in 12 kayak racers and 19 canoe racers who took part in the 2000 Olympic games in Sydney, but the authors did not distinguish between the single and double canoe categories, and the somatotype was provided for canoeists and kayakers together. Within that study, the only significant difference between canoeists who placed in the top 10 in the 2000 Olympics and the other competitors was the value of the ectomorphic component of the somatotype (Ridge et al., 2007). In comparison with the 2000 Olympic canoe sprint racers (Ackland, Orng, Kerr, \& Ridge, 2003) white-water competitors were smaller $(185 \pm 6.2$ vs. $177 \pm 8.0 \mathrm{~cm})$, lighter $(84.8 \pm 6.2$ vs. $73.1 \pm 5.9 \mathrm{~cm})$, and had different somatotype (1.6-5.7-2.2 vs. 1.7-5.4-2.5). Vedat (2012) proceeded in the same inconsistent manner, studying the anthropomorphic parameters of the Turkish national kayak and canoe white-water slalom team and presenting the results for all men's kayak and canoe categories together. These categories, however, differ in the demands they place on athletes' strength, and it is thus not appropriate to combine data from the various categories together (Bílý, 2002), as previous researchers have shown that the anthropometric parameters and somatotype are different between kayakers and canoeists (Hagner-Derengowska et al., 2014). In the study by Bílý, Süss, \& Buchtel (2011), the categories were properly separated, but the number of anthropometric parameters tracked was very low and the authors used bioelectrical impedance to measure the athletes. Although this method is commonly used, the readings can be 
affected by hydration status (Lukaski, Bolonchuk, Hall, \& Siders, 1986), consumption of a meal (Slinde \& Rossander-Hulthén, 2011), and exercise (Abu Khaled, McCutcheon, Reddy, Pearman, Hunter, \& Weinsier, 1988; Dehghan \& Merchant, 2008). On the contrary, there are advantages of using skinfold measurements (SKF), which do not require large pieces of equipment, is financially affordable, and is accessible all around the world. The SKF method requires only the skill and experience of the examiner (Riegerová \& Ulbrichová, 1993) and the caliper of the right type. Therefore, it is widely recommended (Máček \& Máčková, 2011; Garves et al., 2006; Riegerová, Přidalová, \& Ulbrichová, 2006) and may be useful to provide more anthropometric measures using a quick and cost-effective method.

Analysis of the literature has shown that there is still a lack of information explaining the anthropometric and somatotype differences between elite white-water paddlers and the wider group of performance paddlers, especially in the single-canoe category $(\mathrm{C} 1)$. Therefore, the objective of this study was to determine the anthropometric and somatotype differences between 5 elite $\mathrm{C} 1$ paddlers who qualified for the Czech national team (NT) and other high performance Czech C1 racers who did not qualify (DNQ).

Findings can help all performance athletes with both short and long term ambitions for the inclusion to the National Team, because they can better understand their own limits or reserves, or they can better target their goals. Our findings can also help in the field of the talent identification and development.

\section{METHODS}

A total of 17 male $\mathrm{C} 1$ slalom paddlers were measured using a battery of 40 anthropometric parameters before competing in selection races for the Czech national team (the 3 best $\mathrm{C} 1$ competitors and 2 alternates were nominated) and for the 2016 Olympic Games in Rio de Janeiro (1 C1 paddler was nominated). Only paddlers competing in the highest Czech competition series - Czech Cup $(n=38-42)$ with Performance Class I $(n=20)$ could participate in our study. The entire base sample was addressed. Three competitors could not participate because of illness or staying abroad. Selection races are a part of the Czech Cup series every year. All participants read and signed a consent form before participating in the study, which was approved (no. 052/2016) by the ethics committee at the Faculty of Physical Education and Sport in Charles University.

The measurements took place over a single day, 4 weeks before the nomination races for the Czech national team prior to the 2016 Olympic Games in Rio de Janeiro. To eliminate inter-rater variability, all measurements were conducted by a single experienced examiner from the Faculty's Biomedical laboratory. All unilateral measurements were performed on the right side of the body with the exception of the forearm and biceps, which were conducted on the dominant arm in terms of paddling strength (Bílý et al., 2010). Body mass, 7 direct lengths, 7 segmental girths, 7 breadth measurements, 1 depth measurement and 3 calculated ratios were determined according to Norton \& Olds (1996), similar to the measurements conducted by Ridge et al. (2007), Ackland et al. (2003), and Bloomfield, Ackland, \& Elliot (2003). To determine somatotype, 4 skinfold sites were measured (triceps, scapula, calf and supraspinale) using Harpenden calipers with a precision of $0.1 \mathrm{~cm}$ (pressure on skinfold $10.0 \mathrm{~g} \mathrm{~mm}^{2}$ ). 
The somatotype was calculated using the method of Carter \& Heath (1990) using the software programme Somatotype 1.2.5 (available from: http://goulding.ws/somatotype). Another 10 skinfold sites were measured (cheek, chin, chest I, triceps, back, abdomen, chest II, hip, thigh, calf) to calculate body fat percentage according to prediction equation by Pařízková (1977) in Riegerová, Přidalová, \& Ulbrichová (2006), using Best calipers with a precision of $0.1 \mathrm{~cm}$ (pressure on skinfold $28 \mathrm{~g} / \mathrm{mm}^{2}$ ).

Independent student's T-tests were conducted in MS Excel 2010 and statistical significance was set at $p<0.05$ as in the morphological study of 2000 Olympic white-water athletes by Ridge et al. (2007). To assess data normality, the method of comparing the arithmetic mean and median was used (Netolická, 2008).

\section{RESULTS}

All data were normally distributed. Descriptive statistics for absolute and relative anthropometric parameters are presented in Table 1. Somatotypes are presented in Figure 1.

Table 1 Statistics for absolute and relative size of anthropometric parameters

\begin{tabular}{|c|c|c|c|c|c|}
\hline & \multicolumn{2}{|c|}{$\begin{array}{c}\text { Competitors included in the } \\
\text { national team of the Czech } \\
\text { Republic }(n=5)\end{array}$} & \multicolumn{2}{|c|}{$\begin{array}{l}\text { 0ther competitors of } 1 \text { st and } \\
\text { master class that did not qualify } \\
\text { for the national team }(n=12)\end{array}$} & \multirow{2}{*}{$\begin{array}{c}\begin{array}{c}\text { Statistical } \\
\text { significance } \\
\text { of differencec }\end{array} \\
P\end{array}$} \\
\hline & Mean and SD & Range & Mean and SD & Range & \\
\hline Age (years) & $26.4 \pm 3.9$ & $21.2-32.0$ & $18.9 \pm 3.6$ & $16.0-30.0$ & 0.007 \\
\hline Body weight $(\mathrm{kg})$ & $76.2 \pm 4.4$ & $69.2-81.4$ & $73.8 \pm 4.5$ & $65.1-80.7$ & 0.18 \\
\hline Body height $(\mathrm{cm})$ & $179.2 \pm 1.5$ & $176.6-181.1$ & $180.9 \pm 4.6$ & $175.6-191.7$ & 0.14 \\
\hline BMI $\left(\mathrm{kg} \cdot \mathrm{m}^{-2}\right)$ & $23.9 \pm 1.8$ & $21.1-25.9$ & $22.6 \pm 1.6$ & $18.7-24.8$ & 0.13 \\
\hline Sitting height $(\mathrm{cm})$ & $93.7 \pm 1.5$ & $91.8-95.8$ & $92.9 \pm 2.9$ & $87.1-99.7$ & 0.23 \\
\hline Sitting height/body height (\%) & $52.3 \pm 1.0$ & $50.5-53.6$ & $51.3 \pm 0.9$ & $49.4-52.9$ & 0.08 \\
\hline Arm span $(\mathrm{cm})$ & $187 \pm 4.5$ & $183.5-195.0$ & $186.1 \pm 3.4$ & $181.0-193.0$ & 0.36 \\
\hline Arm span/body height (\%) & $104.4 \pm 2.0$ & $101.9-107.7$ & $102.9 \pm 1.9$ & $99.8-105.8$ & 0.11 \\
\hline Arm length $(\mathrm{cm})$ & $33.0 \pm 1.6$ & $30.5-35.2$ & $32.1 \pm 1.5$ & $29.5-34.2$ & 0.18 \\
\hline Forearm length $(\mathrm{cm})$ & $30.0 \pm 2.3$ & $24.5-30.2$ & $26.1 \pm 1.2$ & $24.5-28.5$ & 0.28 \\
\hline Thigh length $(\mathrm{cm})$ & $42.2 \pm 3.1$ & $37.0-45.5$ & $42.6 \pm 2.1$ & $40.0-47.0$ & 0.41 \\
\hline Leg length (cm) & $38.5 \pm 2.8$ & $35.0-42.5$ & $38.2 \pm 2.2$ & $34.2-42.5$ & 0.43 \\
\hline Shoulder breadth $(\mathrm{cm})$ & $39.3 \pm 0.8$ & $38.0-40.3$ & $39.9 \pm 1.1$ & $38.5-42.0$ & 0.14 \\
\hline $\begin{array}{l}\text { Anterior-Posterior chest depth } \\
(\mathrm{cm})\end{array}$ & $20.0 \pm 1.2$ & $18.2-21.4$ & $20.0 \pm 1.9$ & $17.8-24.0$ & 0.45 \\
\hline Humerus breadth $(\mathrm{cm})$ & $7.4 \pm 0.3$ & $6.8-7.8$ & $7.1 \pm 0.4$ & $6.1-7.7$ & 0.12 \\
\hline Femur breadth $(\mathrm{cm})$ & $10.0 \pm 0.5$ & $9.60-10.7$ & $10.0 \pm 0.5$ & $9.1-10.8$ & 0.37 \\
\hline Flexed dominant arm girth $(\mathrm{cm})$ & $35.6 \pm 1.5$ & $33.1-37.6$ & $33.5 \pm 1.7$ & $30.5-36.0$ & 0.020 \\
\hline $\begin{array}{l}\text { Flexed dominant forearm girth } \\
(\mathrm{cm})\end{array}$ & $27.8 \pm 0.6$ & $27.2-28.6$ & $26.8 \pm 1.4$ & $25.0-29.8$ & 0.040 \\
\hline Chest girth $(\mathrm{cm})$ & $98.3 \pm 2.4$ & $94.0-101.0$ & $93.9 \pm 4.7$ & $85.0-102.0$ & 0.016 \\
\hline
\end{tabular}




\begin{tabular}{l|c|c|c|c|c}
\hline Waist girth $(\mathrm{cm})$ & $79.2 \pm 1.8$ & $77.0-82.0$ & $77.5 \pm 3.5$ & $70.0-83.2$ & 0.11 \\
\hline Hip girth $(\mathrm{cm})$ & $92.1 \pm 2.4$ & $88.5-94.7$ & $92.8 \pm 2.3$ & $87.0-95.7$ & 0.32 \\
\hline Thigh girth $(\mathrm{cm})$ & $50.3 \pm 1.5$ & $47.5-52.0$ & $48.6 \pm 2.9$ & $44.5-53.5$ & 0.09 \\
\hline Calf girth $(\mathrm{cm})$ & $35.0 \pm 1.1$ & $33.5-36.2$ & $34.7 \pm 2.1$ & $31.5-38.2$ & 0.15 \\
\hline Sum of 4 skinfoldsa $(\mathrm{mm})$ & $20.6 \pm 3.6$ & $17.5-27.5$ & $24.8 \pm 2.0$ & $19.5-28.0$ & $\mathbf{0 . 0 3 0}$ \\
\hline Endomorphy & $1.40 \pm 0.4$ & $1.0-2.0$ & $1.6 \pm 0.2$ & $1.2-1.9$ & 0.13 \\
\hline Mesomorphy & $5.6 \pm 1$ & $4.1-7.0$ & $4.6 \pm 1.0$ & $3.1-6.9$ & 0.06 \\
\hline Ectomorphy & $2.3 \pm 0.8$ & $1.4-3.5$ & $3.1 \pm 0.9$ & $1.9-5.4$ & 0.06 \\
\hline Sum of 10 skinfoldsb $(\mathrm{mm})$ & $49.2 \pm 9.9$ & $39.0-68.0$ & $54.3 \pm 5.6$ & $43.0-65.0$ & 0.18 \\
\hline Body fat (\%) & $7.5 \pm 2.3$ & $6-12.2$ & $9.1 \pm 1.6$ & $4.8-11.8$ & 0.13 \\
\hline
\end{tabular}

a Sum of 4 skinfolds by Carter and Heath (1990): triceps, scapula, calf and supraspinale. Measurement conducted to calculate somatotype.

b Sum of 10 skinfolds by Pařízková (1977): cheek, chin, chest I, triceps, back, abdomen, chest II, hip, thigh, calf. Measurement conducted to establish \% body fat.

' The statistical significance of the difference between the groups of racers on or not on the national team was determined based on the results in nomination races that took place 4 weeks after the anthropometric measurements.

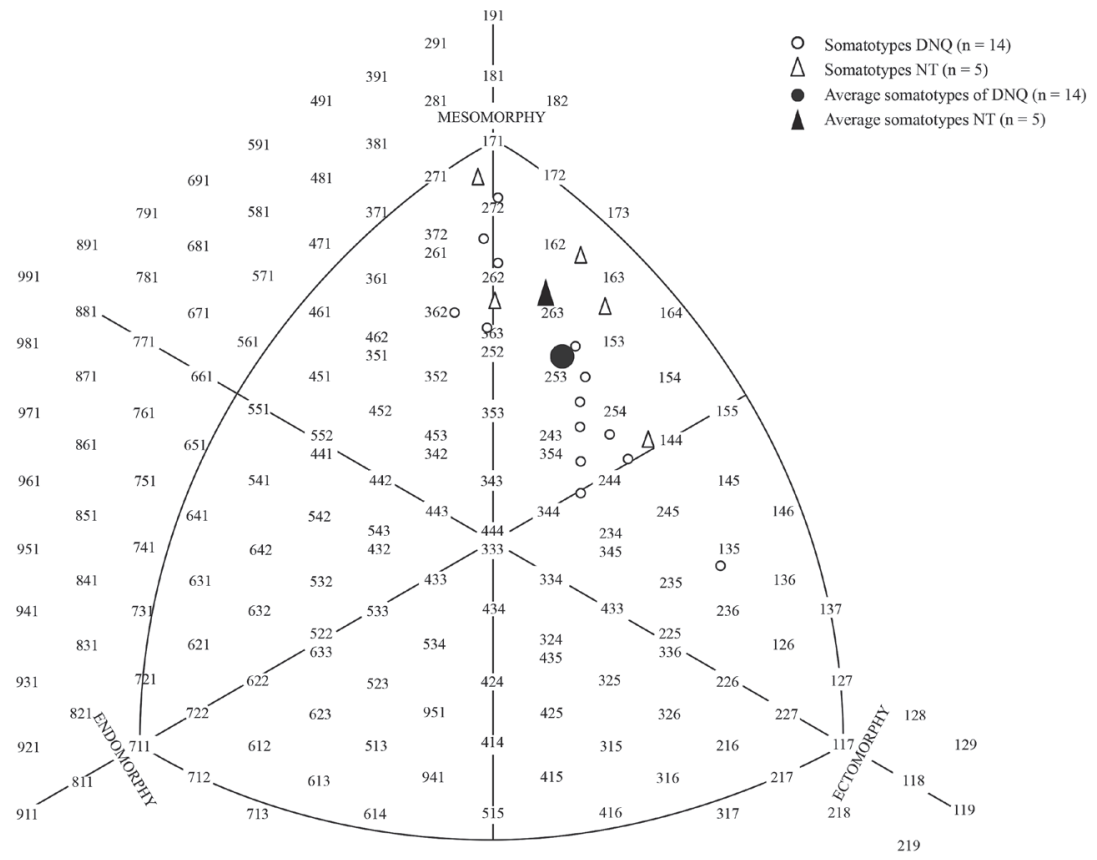

Figure 1 Somatograph of the NT a DNQ competitors

\section{List of abbreviations}

C1 Single-canoe, type of boat

NT Athletes who were chosen for the Czech national team

DNQ Athletes who did not qualify for the national team

SKF Skinfold measurements

BMI Body mass index 


\section{DISCUSSION}

NT racers had significantly greater arm and chest girths compared to DNQ racers. Additionally, the sum of 4 skinfolds was significantly less in NT, but body fat percentage using a 10-site body composition equation, total body mass, and limb lengths were not statistically different between NT and DNQ. The lack of differences in lower body circumference measurements and total body mass indicate that upper body musculature play a significant role in elite $\mathrm{C} 1$ paddle performance.

The NT paddlers had a greater circumference of the forearm (27.8 \pm 0.6 vs. $26.8 \pm 1.4 \mathrm{~cm})$, upper arm $(35.60 \pm 1.5$ vs. $33.5 \pm 1.7 \mathrm{~cm})$ and chest $(98.3 \pm 2.4$ vs. $93.9 \pm 2.3 \mathrm{~cm}$ ) compared to DNQ. With no differences in total body mass or lower limb circumference, the differences in upper body girth likely contributed to, albeit an insignificant, increased mesomorphic component in NT compared to DNQ (1.4-5.6-2.3 vs. 1.6-4.6-3.1). It is evident from the somatograph that both the elite and sub-elite racers can be characterised as ectomorphic mesomorphs, which is in agreement with the conclusions of Bílý et al. (2011) and Ridge et al. (2007). It is probable that the NT athletes had more muscle mass in the upper limbs and chest than DNQ, while muscle mass of the lower limbs remains minimal. From a coaching standpoint, an ectomorphic mesomorph somatotype is desirable for $\mathrm{C} 1$ paddlers because it allows to the paddler to remain relatively low in body weight while also increasing muscle mass in the upper body to exert more force against the water, enabling quicker acceleration and deceleration of the boat throughout the slalom. Therefore, exaggerating this somatotype by placing a larger focus on upper body resistance training may prove to be beneficial for $\mathrm{C} 1$ paddlers.

It is important to note that while the NT racers displayed larger upper body girths than the DNQ racers, this may be partly credited to the fact that the NT paddlers were older than the DNQ racers $(26.4 \pm 3.9$ vs. $18.9 \pm 3.6$ years). This difference is the result of a number of junior athletes (17 to 18 years old) being among the top twenty Czech racers in the $\mathrm{C} 1$ category. This presents a certain limitation to this study, since, although the younger competitors compete at the national level, their bodies may still be developing and their somatotype may not be definitive (Sigmund et al., 2016). We also concur with the conclusions of Ridge et al. (2007) that NT canoeists were older than DNQ. As older athletes tend to be ranked higher than younger athletes, it is likely that experience plays a large role in performance.

Neither the sum of 10 skinfolds $(\mathrm{NT}=49.2 \pm 9.87 ; \mathrm{DNQ}=54.3 \pm 5.60 \mathrm{~mm}$; $p=0.18)$ nor body fat percentage ( $\mathrm{NT}=7.5 \pm 2.3 \%$; DNQ $=9.1 \pm 1.6 \% ; p=0.13$ ) displayed a difference between groups. Akca \& Muniroglu (2008) reported greater body fat percentages (13.7\%) than those in the present study (7.5-9.1\%), but noted that body composition was negatively correlated with $500 \mathrm{~m}$ flat-water sprint times. Also, they used a different anthropometry method for the determination of body fat percentage - the Siri equation application of Durnin \& Womersley (1974). Although a direct comparison should not be made between white-water slalom and flat-water sprint, the course distance and physiological requirements of the sport are partly similar. Therefore, it can be recommended that white-water canoe athletes should aim to reduce the amount of body fat, which is supported by the data for NT paddlers in the present study. 
Overall the NT racers were similar to the Olympic white-water slalom participants from Sydney 2000 (Ridge et al., 2007) in terms of age (28.1 \pm 5.2 years), somatotype (1.7-5.2-2.5), arm span $(183.8 \pm 7.9 \mathrm{~cm})$ and sitting height $(93.0 \pm 3.9 \mathrm{~cm})$. We also found similarities to the study of Vedat (2012), in which 10 male white-water athletes from the Turkish National Canoe Team had a mean height of $176.2 \pm 5.7 \mathrm{~cm}$, mean body weight of $74.5 \pm 10.7 \mathrm{~kg}$ and mean values of the somatotype components of 2.2-5.0-2.3. Additionally, the white-water slalom racers of the present study were shorter ( 180 vs. $184.3 \mathrm{~cm})$, lighter ( 75 vs. $85.2 \mathrm{~kg})$, and less mesomorphic ( 1.5-5.0-2.5 vs. 1.6-5.7-2.2) than canoe sprinters. Such differences can be attributed to the need for quick acceleration, deceleration, and directional changes in white-water slalom compared to canoe sprint, which may warrant a smaller, lighter body (Ackland, Ong, Kerr, \& Ridge, 2003).

Previous studies (Ridge et al., 2007; Vedat, 2012; Bílý, Süss, \& Buchtel, 2011) agree with our data, in that white-water slalom racers have an average height of about $170-180 \mathrm{~cm}$ and a body mass of $70-80 \mathrm{~kg}$. It has been suggested that a short stature is an identifiable feature of slalom paddlers, as they are among the shortest of all athletes (Norton \& Olds, 1996), which is similar to the mean of a reference population of non-athletes (Riegerová, Kapuš, Gába, \& Ščotka, 2010). A short stature may be of considerable advantage to the slalom paddler, who is reliant on maintaining a low centre of gravity to increase stability in the constantly changing white-water environment (Ridge et al., 2007). In addition, previous studies have shown that a greater body mass is likely a limiting factor for performance (Ridge et al., 2007; Vedat, 2012; Bílý, Süss, \& Buchtel, 2011). Combined, a tall stature and heavy body mass present a problem, as the capacity of contemporary boats is quite small. Another disadvantage for larger athletes is the increased surface area between the boat and the water caused by the boat riding lower in the water, which makes it more difficult to achieve and maintain momentum continuously (Grasgruber \& Cacek, 2008). Only 3 paddlers in the present study exceeded $80 \mathrm{~kg}(80.4-81.4 \mathrm{~kg})$ and it is likely that weight reduction occurred prior to competition, as the races took place 4 weeks later. Thus, greater body weight, and the frequently associated greater height, is likely a limiting anthropometric factor for elite and sub-elite performance.

Lastly, there are some limitations in the present study. First, the relatively small sample size (NT $=5, \mathrm{DNQ}=12$ ) may cause concern, but the purpose of the study was to compare the top elite paddlers in the Czech Republic to other elite paddlers. Therefore, the nature of the research questions required the NT sample size to be low, representing the "elite of the elite" in the country. Future research conducted simultaneously in various countries may provide larger sample sizes and may unveil more significant differences, as many $p$-values in the present study ranged from 0.06-0.18. Second, as previously mentioned, the number of elite paddlers under the age of 20 is quite large in the Czech Republic. As a result, differences in somatotype may be partly credited to maturation and not solely to training. Finally, the present study utilized a battery of 40 anthropometric variables, but no physiological or performance measures. Therefore, future research should aim to determine whether the anthropometric parameters separating NT and DNQ paddlers also associate with physical performance in elite $\mathrm{C} 1$ paddlers. 


\section{CONCLUSIONS}

Single canoeists who qualified for the Czech national team (NT) had greater chest, upper arm, and forearm circumferences than DNQ even though they all had very similar weight and height. These differences support a statistically similar, but practically different, somatotype $(\mathrm{NT}=1.4-5.6-2.3 ; \mathrm{DNQ}=1 \cdot 6-4 \cdot 6-3.1)$. NT $\mathrm{C} 1$ paddlers had lower body fat percentage by $1.6 \%$. The NT group did not differ from the DNQ group in terms of height, sitting height, weight, arm span, or lower body circumference measurements. Therefore, the results of this study indicate that single canoeists aspiring to reach elite levels should practise strength training with an emphasis on the upper limbs and chest muscles, seek to attain a minimum level of body fat, and minimise hypertrophy of the muscles in the lower limbs.

In line with other studies (Ridge et al., 2007; Vedat, 2012; Bílý, Süss, \& Buchtel, 2011) we can to suggest that greater body weight, and the frequently associated greater height, is likely a limiting anthropometric factor for elite and sub-elite performance. Only 3 paddlers in the present study exceeded $80 \mathrm{~kg}(80.4-81.4 \mathrm{~kg})$ and it is likely that weight reduction occurred prior to competition, as the races took place 4 weeks later. Only 1 paddler had more than $190 \mathrm{~cm}$. This can help in talent identification.

\section{REFERENCES}

Abu Khaled, M., McCutcheon, M. J., Reddy, S., Pearman, P. L., Hunter, G. R., \& Weinsier, R. L. (1988). Electrical impedance in assessing human body composition: the BIA method. Am. J. Clin. Nutr., 47(5), 789-792.

Ackland, T. R., Ong, K. B., Kerr, D. A., \& Ridge, B. R. (2003). Morphological characteristics of Olympic sprint canoe and kayak paddlers. Journal of Science and Medicine in Sport, 6(3), 285-294.

Akca, F., \& Muniroglu, S. (2008). Anthropometric - somatype and strength profiles and on - water performance in Turkish elite kayakers. International Journal of Applied Sports Sciences, 20(1), 22-34.

Bílý M. (2002). Komplexni analýza techniky pádlování a jízdy na divoké vodě [doctoral thesis]. Prague: Faculty of Physical Education and Sport, Charles University.

Bílý, M. (2012). Výkonové aspekty ve vodním slalomu [dissertation]. Faculty of Physical Education and Sport, Charles University, Prague.

Bílý, M., Baláš, J., Andrew, J. M., Darryl, J. C., Coufalová, K., \& Süss V. (2010). Effect of paddle grip on segmental fluid distribution in elite slalom paddlers. European Journal of Sport Science, 13(3), 185-190.

Bílý, M., Süss, V., \& Buchtel, M. (2011). Selected somatic factors of white water canoeists. Journal of outdoor activities, 5(2), 30-42.

Bloomfield, J., Ackland, T. R., \& Elliot, B. C. (2003). Applied anatomy and biomechanice in sport. Melbourne, VIC: Blackwell Science.

Carter, J. E. L., \& Heath, B. H. (1990). Somatotyping - Development and Applications. Cambridge: Cambridge University Press.

Dehghan, M., \& Merchant, A. T. (2008). Is bioelectrical impedance accurate for use in large epidemiological studies? Nutr. J., 7(1), 26.

Dokumaci, B., \& Çakir-Atabek, H. (2015). Relationship between Anthropometric Variables, Respiratory Function and Bio-Motoric Properties in Turkish Flat Water Canoe Athletes. International Journal of Social Sciences and Education Research, 1(3), 912-923. 
Durnin, J. V. G., \& Womersley, J. (1974). Body fat assessed from total body density and its estimation from skinfold thickness: measurements on 481 men and women aged from 16 to 72 years. British Journal of Nutrition, 32(1), 77-97.

Fry, R. W., \& Morton, A. R. (1991). Physiological and kinanthropometric attributes of elite flatwater kayakists. Medicine and Science in Sports and Exercise, 23(11), 1297-1301.

Grasgruber, P., \& Cacek, J. (2008). Sportovni geny. Brno: Computer Press.

Graves, J. E., et al. (2006). Anthropometry and body composition measurement. In: Maud, J. M., \& Foster, C. (Eds.), Physiological assessment of human fitness. Champaign, IL: Human Kinetics, pp. 185-225.

Gutnik, B., Zuoza, A., Zuoziene, I., Alekrinskis, A., Nash, D., \& Scherbina S. (2015). Body physique and dominant somatotype in elite and low - profile athletes different specializations. Medicina, 51(4), 247-252.

Hagner-Derengowska, M., Hagner, W., Zubrzycki, I. Z., Krakowiak, H., Slomko, W., Dzierzanowski, M., Rakowski, A., \& Wiacek-Zubrzycka, M. (2014). Body structure and composition of canoeists and kayakers: Analysis of junior and teenage Polish national canoeing team. Biology of Sport, 31(4), 323-326.

Lukaski, H. C., Bolonchuk, W. W., Hall, C. B., \& Siders, W. A. (1986). Validation of tetrapolar bioelectrical impedance method to assess human body composition. J. Appl. Physiol., 60(4), 1327-1332.

Máček, M., \& Máčková, J. (2011). Fyziologie a klinické aspekty pohybové aktivity. Prague: Galén.

Netolická, V. (2008). Testy normality. Bakalářská práce Olomouc: Přírodovědecká fakulta, Univerzita Palackého v Olomouci.

Norton, K., \& Olds, T. (1996). Anthropometrica. Sydney, NSW: UNSW Press.

Pařízková, J. (1977). Body fat and physical fitness: body composition and lipid metabolism in different regimes of physical activity. The Hague: Martinus Nijhoff.

Peterson, J. T., Repovich, W. E., \& Parascand, C. R. (2011). Accuracy of consumer grade bioelectrical impedance analysis devices compared to air displacement plethysmography. Int. J. Exerc. Sci., 4(3), 176-184.

Ridge, B. R., Broad, E., Kerr, D. A., \& Ackland, T. R. (2007). Morphological characteristics of Olympic slalom canoe and kayak paddlers. European Journal of Sport Science, 7(2), $107-113$.

Riegerová, J., Kapuš, O., Gába, A., \& Ščotka, D. (2010). Rozbor tělesného složení českých mužů ve věku 20-80 let (hodnocení tělesné výšky, hmotnosti, BMI, svalové a tukové frakce). Česká antropologie, 60(1), 20-23.

Riegerová, J., Přidalová, M., \& Ulbrichová, M. (1996). Aplikace fyzické antropologie v tělesné výchově a sportu. Olomouc: Vydavatelství Univerzity Palackého.

Riegerová, J., \& Ulbrichová, M. (1993). Aplikace fyzické antropologie v tělesné výchově a sportu. Olomouc: Vydavatelství Univerzity Palackého.

Sigmund, M., Rozsypal, R., Kudláček, M., Kratochvíl, J., \& Sigmundová, D. (2016). Influence of one-year sport activities on the changes in morphological parameters and somatotypes in the current junior members of the Czech national whitewater slalom team. Journal of Physical Education and Sport, 16, 118-124.

Slinde, F., \& Rossander-Hulthén, L. (2001). Bioelectrical impedance: effect of 3 identical meals on diurnal impedance variation and calculation of body composition. Am. J. Clin. Nutr., 74(4), 474-478.

Van Someren, K. A., \& Howatson, G. (2008). Prediction of Flatwater Kayaking Performance. International Journal of Sports Physiology and Performance, 3(2), 207-218.

Van Someren, K. A., \& Palmer, G. S. (2003). Prediction of 200-m sprint kayaking performance. Canadian Journal of Applied Physiology, 28(4), 505-517.

Vedat A. (2012). Somatotypes of male whitewater canoe athletes of the Turkish National Canoe Team. Educational Research and Reviews, 7(24), 526-531. 